\title{
An update on targeted therapies in systemic sclerosis based on a systematic review from the last 3 years
}

\author{
Corrado Campochiaro ${ }^{1}$ and Yannick Allanore ${ }^{2^{*}}$
}

\begin{abstract}
New molecular mechanisms that can be targeted with specific drugs have recently emerged for the treatment of systemic sclerosis (SSc) patients. Over the past 3 years, the achievement of one large phase 3 trial has led to the approval by drug agencies of the first drug licenced for SSc-related interstitial lung disease. Given this exciting time in the SSc field, we aimed to perform a systemic literature review of phase 1, phase 2 and phase 3 clinical trials and large observational studies about targeted therapies in SSc. We searched MEDLINE/PubMed, EMBASE, and ClinicalTrials.gov for clinical studies from 2016 with targeted therapies as the primary treatment in patients with SSC for skin or lung involvement as the primary clinical outcome measure. Details on the study characteristics, the trial drug used, the molecular target engaged by the trial drug, the inclusion criteria of the study, the treatment dose, the possibility of concomitant immunosuppression, the endpoints of the study, the duration of the study and the results obtained were reviewed. Of the 973 references identified, 21 (4 conference abstracts and 17 articles) were included in the systematic review. A total of 15 phase 1/phase 2 clinical trials, 2 phase 3 clinical trials and 2 observation studies were analysed. The drugs studied in phase 1/phase 2 studies included the following: inebilizumab, dabigatran, C-82, pomalidomide, rilonacept, romilkimab, tocilizumab, tofacitinib, pirfenidone, lenabasum, abatacept, belimumab, riociguat, SAR100842 and lanifibranor. All but 3 studies were performed in early diffuse SSc patients with different inclusion criteria, while 3 studies were performed in SSc patients with interstitial lung disease (ILD). Phase 3 clinical trials investigated nintedanib and tocilizumab. Nintedanib was investigated in SSC-ILD patients whereas tocilizumab focused on early diffuse SSc patients with inflammatory features. Two observational studies including $>50$ patients with rituximab as the targeted drug were also evaluated. All these studies offer a real hope for SSc patients. The future challenges will be to customize patient-specific therapeutics with the goal to develop precision medicine for SSc.
\end{abstract}

Keywords: Systemic Sclerosis, Targeted therapy, Interstitial lung disease, Clinical Trial, Observational study, Systematic review

\footnotetext{
* Correspondence: yannick.allanore@me.com

${ }^{2}$ Service de Rhumatologie, Hôpital Cochin, Université de Paris, 27 rue du Faubourg Saint-Jacques, 75014 Paris, France

Full list of author information is available at the end of the article
}

C C The Author(s). 2021 Open Access This article is licensed under a Creative Commons Attribution 4.0 International License, which permits use, sharing, adaptation, distribution and reproduction in any medium or format, as long as you give appropriate credit to the original author(s) and the source, provide a link to the Creative Commons licence, and indicate if changes were made. The images or other third party material in this article are included in the article's Creative Commons licence, unless indicated otherwise in a credit line to the material. If material is not included in the article's Creative Commons licence and your intended use is not permitted by statutory regulation or exceeds the permitted use, you will need to obtain permission directly from the copyright holder. To view a copy of this licence, visit http://creativecommons.org/licenses/by/4.0/. The Creative Commons Public Domain Dedication waiver (http://creativecommons.org/publicdomain/zero/1.0/) applies to the data made available in this article, unless otherwise stated in a credit line to the data. 


\section{Introduction}

Systemic sclerosis (SSc) is an orphan multiorgan connective tissue disease characterized by microangiopathy, immune dysregulation and fibrotic changes affecting the skin and internal organs [1,2]. Although the pathogenesis of SSc is far from being fully understood, multiple pathogenic mechanisms and different cell types have been implicated in the disease process [3]. Chronic vascular injury, endothelial activation and immune activation are all thought to be crucial for secondarily fibroblast activation and related fibrogenesis [4]. The release of different soluble mediators including endothelin-1, chemokines and growth factors together with an increased expression of adhesion molecules and platelet activation can lead to the recruitment and activation of immune inflammatory cells, including type 2 helper (Th2) $\mathrm{T}$ cells that secrete transforming growth factor- $\beta$ (TGF $\beta$ ), interleukin 13 (IL-13) and IL-4 known to promote fibrogenesis; $\mathrm{B}$ cells that produce autoantibodies and IL-6; macrophages that release TGF $\beta$, IL-1 and IL- 6 and dendritic cells that secrete type 1 interferon (IFN) [4]. Furthermore, activated platelet can increase the production of platelet-derived growth factor (PDGF), thrombin, thromboxane, serotonin and platelet factor 4 (PF4). All these mediators contribute to the phenotypic differentiation of fibroblasts into myofibroblasts which are responsible for the generation of reactive oxygen species (ROS) and other fundamental release of growth factors that include TGF $\beta$, connective tissue growth factor $(\mathrm{CCN} 2)$ and PDGF. Regulatory pathways activated by lipid mediators and intracellular molecules can further modulate extracellular matrix (ECM) production (see Fig. 1). In this review, we will go through the recent evidences obtained in phase 1 , phase 2 and phase 3 clinical trials and large observational studies about targeted therapies in SSc over the last 3 years.

\section{Methods}

The study protocol was developed according to the Preferred Reporting Items for Systematic Reviews and Meta-Analyses (PRISMA) guidelines. Eligibility criteria are as follows: phase 1 , phase 2 , phase 3 or observational studies reporting the use of targeted therapies in the treatment of SSc patients for skin or lung involvement. Applying the PICOs framework, we evaluated publications that fulfilled the following study characteristics:

(1) Participants: Adult ( $\geq 18$ years old) patients with a diagnosis of systemic sclerosis

(2) Interventions: Studies reporting the outcome of targeted therapies for lung or skin involvement in SSc patients.

(3) Comparison: Where applicable, comparison of lung or skin outcomes in the group of SSc patients treated with the targeted therapy versus control group was made.

(4) Outcomes: Effectiveness of targeted therapies for lung or skin involvement in SSc patients. Both primary and secondary efficacy endpoints and safety endpoints were included.

(5) Study design: (i) phase 1, phase 2 or phase 3 trials, (ii) observational studies including $\geq 50 \mathrm{SSc}$ patents with targeted therapies as the primary treatment in patients with SSc for skin or lung involvement, (iii) articles published in English, (iv) articles published from January 2016 to July 2020. Post hoc analyses of clinical trials were excluded.

Information source and search criteria are as follows: A literature search of MEDLINE/PubMed, ClinicalTrials. gov and EMBASE databases was performed. The following search criteria were used: ((systemic sclerosis) OR (scleroderma)) AND ((phase 1) OR (phase 2) OR (phase 3) OR (trial) OR (observational)).

For study selection, abstracts' titles were screened independently by both reviewers (CC and YA) for relevance and eligibility of studies for full text review. Divergences in agreement were resolved through discussion at each step of the study selection process.

For data extraction, data was extracted by $\mathrm{CC}$ and reviewed by YA. The data extraction form included the following details about the studies: date of publication, study population and intervention characteristics, the trial drug used, the molecular target engaged by the trial drug, the inclusion criteria of the study, the treatment dose, the possibility of concomitant immunosuppression, the endpoints of the study, the duration of the study, adverse effects and outcomes.

For risk of bias assessment, since some of the study included were not randomized, risk of bias was assessed for these studies using the Risk of Bias Assessment Tool for Non-randomized Studies (RoBANS). Studies' risk of bias was rated as "high", "low" or "unclear" on each of the dimensions (selection, performance, detection, attrition and reporting).

\section{Results}

Searches of MEDLINE/PubMed and EMBASE (668 records) and ClinicalTrial.gov (305 records) were undertaken identifying a total of 973 records. After removal of duplications $(\mathrm{n}=177)$, the remaining 796 articles were screened for eligibility during a title and abstract review undertaken by both reviewers. A total of 20 studies fulfilled inclusion criteria including 4 conference abstracts and 16 full articles. No studies were excluded due to language. There was complete agreement between the reviewers for studies' eligibility for full text review. A total of 16 phase 1 /phase 2 clinical trials, 2 phase 3 clinical 


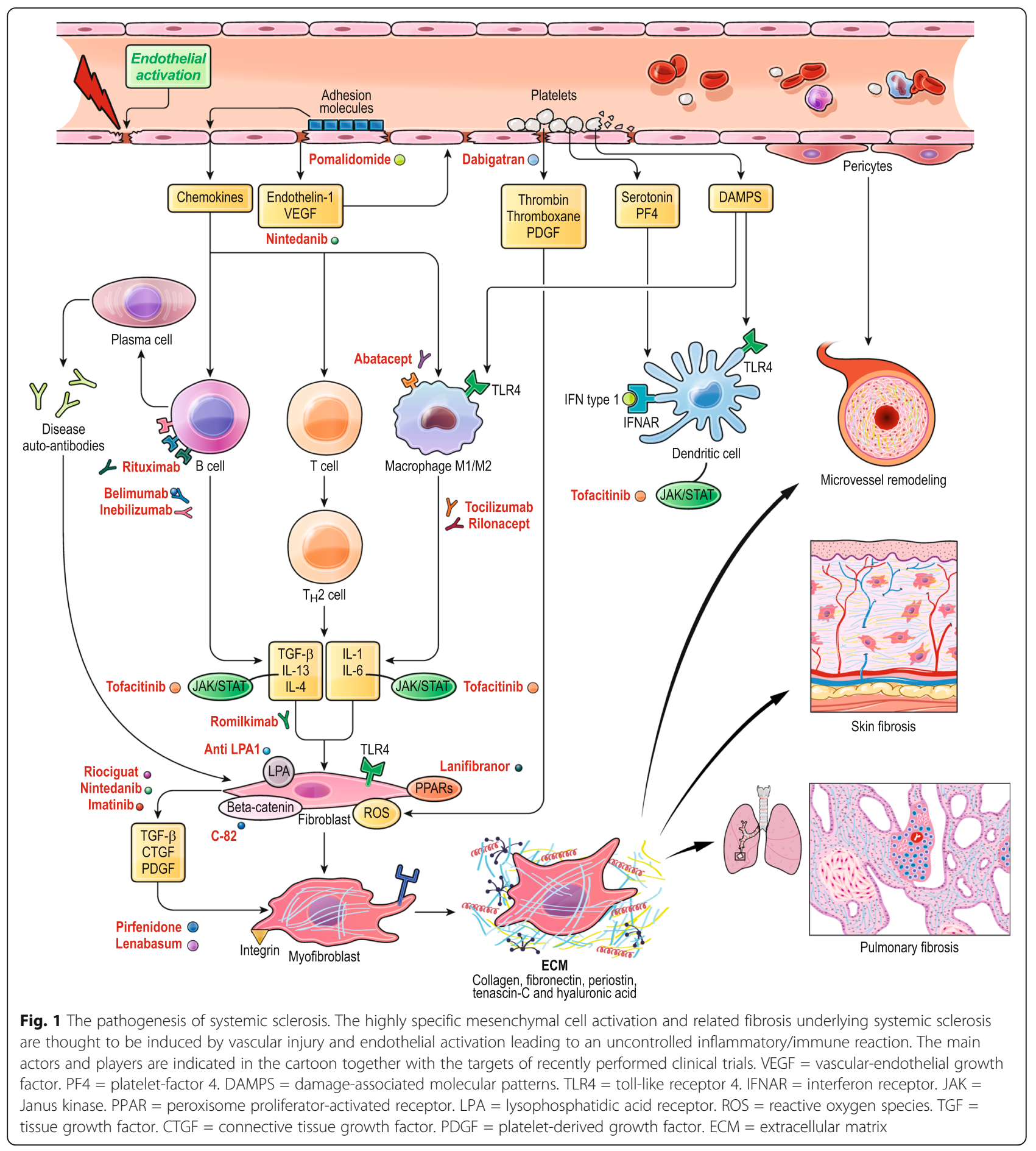

trials and 2 observation studies were analysed. An overview of the study selection process is summarized in Fig. 2.

\section{Phase 1-2 trials}

Inebilizumab

CD19 is critically involved in establishing intrinsic B cell signalling thresholds through modulating both $\mathrm{B}$ cell receptor-dependent and independent signalling; it plays a critical role in maintaining the balance between humoral, antigen-induced response and tolerance induction [5]. Inebilizumab (MEDI-551) is an anti-CD19 monoclonal antibody that leads to antibody-dependent, cell-mediated cytotoxicity of B cells [6]. A phase I, randomized, placebo-controlled, escalating, single-dose study was performed in SSc patients (both limited and 


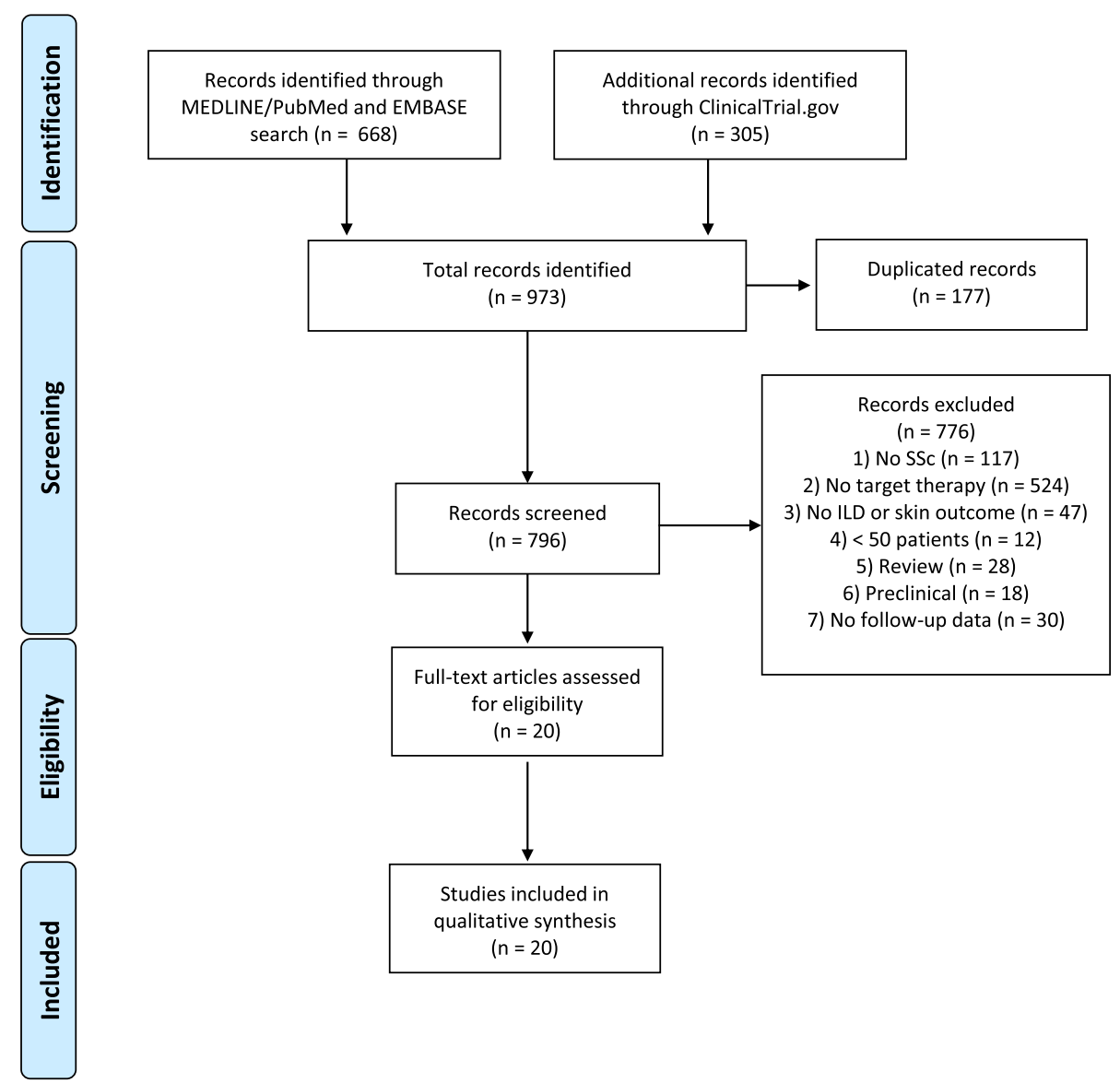

Fig. 2 Flowchart summarizing the study selection process for systematic literature review

diffuse cutaneous) [7]. Twenty-eight patients were enrolled, 24 of these received a single dose of inebilizumab of $0.1-10 \mathrm{mg} / \mathrm{kg}$. The vast majority (96\%) of patients treated with inebilizumab experienced treatmentemergent adverse events (compared to $75 \%$ of placebo patients), the most common being nausea (17\%) and fatigue (17\%). Drug-related side effects were classified as mild and 4 infusion-related reactions were observed. Only two serious adverse events were recorded in the inebilizumab group: supraventricular tachycardia and subclavian vein thrombosis. A potential effect of inebilizumab on skin thickness but not on pulmonary function tests was observed as the mean modified Rodnan skin score (mRSS) change from baseline to day 85 in the inebilizumab group was $-5.4 \pm 4.2$ compared to $2.3 \pm 6.1$ in the placebo group. No clear relationship was found with the drug dose. Conversely, circulating B cell depletion was observed in a dose-dependent fashion.

\section{Dabigatran}

Coagulation was originally thought to be an acute and transient response to tissue injury, responsible primarily for promoting haemostasis by initiating the formation of fibrin plugs to enmesh activated platelets within the walls of damaged blood vessels. However, there is now mounting evidence that coagulation plays a critical role in orchestrating inflammatory and fibroproliferative responses during wound healing, as well as in a range of pathological contexts across several organ systems [8]. Dabigatran, a direct thrombin inhibitor, was shown to attenuate organ fibrosis in a mouse model of SSc [9]. Moreover, thrombin was also demonstrated to stimulate fibroblast proliferation and myofibroblast transition [10]. Dabigatran has been studied in a 6-month, phase 1, prospective, single-centre, open-label study in SSc patients with interstitial lung disease (ILD) [11]. The dose was $75 \mathrm{mg}$ twice daily. Due to the increased risk a bleeding, patients with history of gastrointestinal haemorrhage or gastric antral vascular ectasia were excluded. Exploratory endpoints included patient-reported outcomes, pulmonary function tests and mRSS at months 3 and 6. A total of 15 patients were enrolled. Over the study period, no serious adverse event was observed and dabigatran was well-tolerated. A significant improvement in the mRSS was observed (- 6.6 $\pm 6.4, \mathrm{p}=0.002$ ), but no significant modification in the lung function tests (\%FVC predicted, \%FEV1 predicted and $\%$ DLCO predicted) was recorded. 


\section{C-82}

Several lines of evidence suggest that Wnt signalling is implicated in SSc skin fibrosis [12]. C-82 blocks the interaction between $\beta$-catenin and the transcriptional co-activator and acetyltransferase proteins $\mathrm{CBP}$ and p300 [13], leading to the inhibition of Wnt-activated genes. A placebo-controlled, double-blinded clinical trial in patients with early (median disease duration 8 months) dcSSc was performed with daily C-82 topical formulation for 4 weeks [14]. Although no clinical effect (mRSS including the local skin score on each forearm at baseline and after 4 weeks of treatment) was observed over the study period, repeated skin biopsies demonstrated a weak downregulation of THBS1 and COMP and an upregulation of two clusters of genes in subcutaneous fat cells that negatively correlate with the severity of skin involvement in SSc. The authors concluded that, as suggested by gene expression analysis, longer treatment with topical C-82 might promote fat regeneration in SSc skin.

\section{Pomalidomide}

Pomalidomide (POM) is an anti-angiogenic and immunomodulatory molecule similar to thalidomide. POM binds to cereblon which is responsible for Ikaros and Aiolos degradation and eventually leads to immunemodulation of myeloid and lymphoid cells [15]. A previous open-label, dose-escalating, 12-week study had shown a beneficial effect of thalidomide in skin fibrosis and marginally in gastroesophageal reflux symptoms and digital ulcer healing in 11 SSc patients [16]. Furthermore, biopsies from SSc patients treated with thalidomide had suggested a pro-Th1 immunomodulatory effect for thalidomide. Given this background, a Phase 2, multicentre, randomized, double-blind, placebocontrolled, parallel-group study was conducted in SSc patients with ILD [17]. Fifty nine patients were screened and twenty-three SSc patients were randomized 1:1 to POM $1 \mathrm{mg}$ once daily or placebo for 52 weeks of blinded treatment and a 2-year open-label extension phase. The endpoints of the study were the changes in \% predicted forced vital capacity (\%pFCV), mRSS, and gastrointestinal (GI) symptomatology evaluated through the UCLA Scleroderma Clinical Trials Consortium Gastrointestinal Tract (SCTC GIT 2.0) questionnaire. Unfortunately, although POM was generally well-tolerated, subjects' enrolment was discontinued early because of insufficient recruitment (original targeted sample size was 88 patients) and an interim analysis showed no statistically significant improvement in any of the 3 coprimary efficacy endpoints (changes from baseline in FVC, mRSS, or UCLA SCTC GIT 2.0 at week 24 or week 52). Unfortunately, no clear conclusions could be drawn because too few subjects were enrolled.

\section{Rilonacept}

Rilonacept is a dimeric fusion protein consisting of the human interleukin-1 receptor component (IL-1R1) and IL-1 receptor accessory protein (IL-1RAcP), it is also known as "IL-1 Trap" and it binds and neutralizes IL-1 $\beta$ thus preventing IL-1 from binding with IL-1 cell surface receptors. Rilonacept also binds IL-1alpha and IL-1 receptor antagonist but with reduced affinity [18]. Although the exact mechanism is still uncertain, IL-1 family and inflammasome activation have been implicated in murine models of fibrosis [19]. For these reasons, a phase I/II biomarker, randomized, double-blind, placebo-controlled trial of rilonacept was performed in SSc patients [20]. The primary endpoint was the level of skin expression of the 2G SSc gene biomarkers (THBS1 and MS4A4) as surrogate for the mRSS, while the secondary endpoint was the change in the mRSS. Nineteen patients were randomized 2:1 rilonacept $320 \mathrm{mg}$ loading dose at day 0 ad then $160 \mathrm{mg}$ weekly versus placebo. Skin biopsies were obtained before rilonacept treatment initiation and at week 7 . Both the primary and the secondary endpoints were not met in this short-term trial as after 6 weeks no modification in gene expression or in the mRSS between treated and placebo patients were observed.

\section{Romilkimab}

Romilkimab is a bispecific monoclonal antibody that binds and neutralizes both IL-4 and IL-13 [21]. These are Th2-derived cytokines that have been found to be elevated both in the serum and in the skin biopsies of SSc patients and have also been implicated in the fibrotic pathway of SSc [22]. Moreover, mice with genetic deletion of IL-13 are protected from fibrosis [22]. A phase 2A, randomized, double-blind, placebo-controlled, 24week trial was performed in dcSSc patients [23]. Ninetyseven early (disease duration $\leq 36$ months) dcSSc patients, with or without background immunosuppressive therapy, were randomized 1:1 to romilkimab $200 \mathrm{mg}$ sc or placebo. The primary endpoint of the study was the mean change in mRSS, secondary endpoints were FVC/ DLCO and Health Assessment Questionnaire - Disability Index (HAQ-DI) questionnaire. After 24 weeks, patients treated with romilkimab showed a statistically significant (one-sided $\mathrm{p}$ value $=0.029$ ) improvement in the mRSS $(-4.76 \pm 0.86$ versus $-2.45 \pm 0.85$ in the placebo group). A subgroup analysis suggested also an additive effect between background immunosuppressive therapy and romilkimab. While no secondary endpoint was met (romilkimab was associated with a reduced decline in FVC), exploratory endpoints suggested a possible effect of romilkimab on overall pain, Raynaud's phenomenon, digital ulcers and quality of life (EQ-5D$5 \mathrm{~L}$ questionnaire). Side effects were similar in the two 
groups and 1 death occurred in both arms due to SScrelated complications.

\section{Tocilizumab}

Tocilizumab (TCZ) is an interleukin 6 receptorinhibitor. IL-6 has been deeply implicated in the pathogenesis of SSc. Indeed, IL-6 has major role in both B and $\mathrm{T}$ cell differentiation and fibroblasts transformation into activated myofibroblasts which are fundamental for extracellular matrix production [24]. Importantly, in the bleomycin-induced SSc mouse model, IL-6 blockade was associated with improvement in skin fibrosis and reduction in $\alpha$ smooth-muscle actin protein expression and myofibroblast counts [25]. In vivo studies have demonstrated high IL- 6 concentrations in the sera and skin biopsies of SSc patients and its levels are associated with more severe disease activity and disease progression together with reduced life expectancy [26]. Moreover, IL-6 levels can predict the extent of skin involvement in early SSc patients [27]. The results of a phase 2, randomized, double-blind, placebo-controlled trial investigating the safety and efficacy of subcutaneous TCZ in adults SSc patients (faSScinate trial) were published in 2016 [28]. Patients with early disease (disease duration $\leq 5$ years) and enriched for inflammatory phase were assigned with a 1:1 ratio to TCZ $162 \mathrm{mg}$ sc weekly or placebo. Background immunosuppressant was not allowed. The primary endpoint was the mean change in the mRSS at 24 weeks. Eighty-seven patients were enrolled. Although the primary endpoint was not met, the mean mRSS reduction favoured the TCZ group $(-2.70,95 \% \mathrm{CI}-5.85$ to $0.45 ; \mathrm{p}=0.0915)$. A further and almost significant improvement was observed at 48 weeks in TCZ-treated patients compared to placebo $(-3.55,95 \% \mathrm{CI}-7.23$ to $0.12 ; \mathrm{p}=0.0579$ ). Moreover, a significantly smaller decrease in FVC in the tocilizumab group compared to placebo was observed at 24 weeks (TCZ - $34 \mathrm{~mL}$ versus PBO - $171 \mathrm{~mL} ; \mathrm{p}=0.0368)$. No significant differences were observed in disability, fatigue, itching or patient' or clinician's global disease severity. Although the incidence of serious adverse events was similar between the two groups (33\% vs $34 \%$ ), serious infections were more common in the TCZ group (16\% vs $5 \%$ ) and one patient in the TCZ group died. These encouraging results paved the way to the phase 3 trial of tocilizumab in SSc (focuSSced trial) whose results are discussed in the "Phase 3 Trials" paragraph.

\section{Tofacitinib}

The JAK/STAT pathway is the principal signalling mechanism for several cytokines and growth factors [29]. STAT3 is part of the JAK/STAT pathway and has a critical role in skin and lung fibrosis [30]. Tofacitinib is a "pan JAK inhibitor" as it has a low JAK selectivity being able to block JAK1, JAK2, and JAK3 [31]. Some major mediators which are deemed fundamental in SSc pathogenesis are indeed involved in JAK/STAT signalling pathway: IL-6, IFN type 1 and 2 and most importantly IL-4 and IL-13 [32]. Moreover, different mouse models of SSc showed a potent anti-fibrotic effect for tofacitinib [30]. The safety and efficacy of tofacitinib in SSc was recently tested in a phase I/II, 6-month, double-blind, randomized placebo-controlled trial conducted in early ( $\leq$ 60 months) dcSSc patients [33]. Tofacitinib was used at a dose of $5 \mathrm{mg}$ twice a day and stable background immunosuppressive therapies were allowed. The primary outcome was the proportion of patients who experienced $\geq$ Grade 3 adverse events. Secondary endpoints were the mRSS at month 6, HAQ-DI, patient and physician global assessments, and the ACR composite measure: Combined Response Index in Systemic Sclerosis (CRISS). Fifteen patients were randomized 2:1. Thirteen patients were on stable daily dose of immunosuppressive drugs (12 on mycophenolate mofetil (MMF) and 1 on methotrexate (MTX)). Over the study period, tofacitinib was well tolerated with no patient experiencing $\geq$ Grade 3 adverse events. A trend towards improvement of clinical outcome measures was observed. This preliminary study supports further evaluation of tofacitinib in SSc.

\section{Pirfenidone}

Pirfenidone is a synthetic anti-fibrotic agent already approved by the FDA for the treatment of patients with idiopathic pulmonary fibrosis [34]. In vitro studies showed that pirfenidone inhibits myofibroblast differentiation and blocks TGF- $\beta$ and STAT-3 activation [35]. The safety and efficacy of pirfenidone was evaluated in an open-label, 16-week, phase II trial in SSc-ILD patients randomized 1:1 to either a 2- or 4-week pirfenidone titration starting at $801 \mathrm{mg}$ daily and titrating up to 2403 mg daily maintenance dose (LOTUSS trial) or placebo [36]. Concomitant background immunosuppressive therapy was allowed. Eligibility criteria included disease duration $\leq 7$ years, \%predicted $\mathrm{FVC}>50 \%$ and DLCO > $40 \%$. The primary endpoint was the assessment of adverse events, secondary endpoints were the change in \%predicted FVC and DLCO, mRSS and patient-reported outcomes (Mahler baseline and Transition Dyspnoea Indices, HAQ-DI and patient's global assessment). Sixtythree patients were enrolled and the vast majority (96.8\%) experienced adverse events especially during the titration period. The most common adverse events were nausea, headache and fatigue and were reported regardless of the titration schedule. Notably, more patients in the 2-week titration group discontinued the treatment compared to patients treated with the 4-week titration scheme. $63.5 \%$ of patients were on MMF therapy but its concomitant use did not affect tolerability. No change in 
disease outcomes was observed. In conclusion, while pirfenidone was globally well tolerated in SSc-ILD patients especially in patients treated with 4-week titration scheme no conclusion of its efficacy could be drawn. This study paved the way to the ongoing Scleroderma Lung Study III where pirfenidone is used in combination with MMF (clinicaltrials.gov NCT03221257).

\section{Lenabasum}

Lenabasum is a selective type 2 cannabinoid receptor agonist [37]. Cannabinoid 2 receptors are mainly expressed on immune cells and tissue-resident stromal cells and their activation has been demonstrated to reduce inflammation and tissue fibrosis with only minimal psychoactive effects [38]. A double-blind, randomized, placebo-controlled, 16-week, Phase 2 trial was performed in early (<6 years disease duration) dcSSc patients [39]. Forty-two patients were enrolled and they were allowed to remain on stable background immunosuppression. Patients were treated with the following scheme: $5 \mathrm{mg} /$ day, $20 \mathrm{mg} /$ day or $20 \mathrm{mg}$ bis in die for 4 weeks and then $20 \mathrm{mg}$ bis in die for 8 weeks. The primary endpoint was CRISS scores. No serious or severe adverse events related to lenabasum were observed. Adverse events that occurred in more than $10 \%$ of subjects during 16 weeks with either placebo or lenabasum (\% pbo vs \% lenabasum) were dizziness (13 vs $22 \%$ ), fatigue (7 vs $19 \%$ ), headache (7 vs $11 \%)$, upper respiratory tract infection (0 vs $11 \%)$.

At week 16, patients treated with lenabasum (merge of the 2 treated groups) had a significant improvement in CRISS scores compared to placebo patients $(\mathrm{p}=0.044)$. No dosing effect was observed. Skin biopsies were also taken and they showed a reduction in key genes implicated in inflammation and fibrosis only in lenabasumtreated patient. The trial was followed by a long-term open-label safety and efficacy study [40]. Patients who had completed the 16-week Phase 2 study were enrolled to continue with lenabasum $20 \mathrm{mg}$ twice a day. Thirtysix patients were enrolled and 26 patients were treated for $>92$ weeks. At week 92, the vast majority of patients experienced at least 1 adverse event classified as mild or moderate. Notably, only in 7 (19\%) patients the adverse event was considered related to lenabasum (fatigue, mild disturbances in attention and mild lethargy). The longterm study lenabasum supported its efficacy as improvements were observed in CRISS scores (median score 0.96), mRSS (mean decline 10.3 from baseline), HAQDI, physician global assessment and itch. \%predicted FVC values declined by $3.2 \%$ from study start, but the trial design of this open period limits the conclusion. In conclusion, lenabasum has shown an acceptable safety and tolerability profile and its potential efficacy in several endpoints, although several methodological limitations have emerged (merge of the doses, shortterm study, modest sample size). Unfortunately, while the results of the phase 3 double-blind, randomized, placebo-controlled study assessing the efficacy and safety of lenabasum in dcSSc (RESOLVE-1) have not yet been published, a press release in September 2020 stated that the study did not meet the primary endpoint (CRISS).

\section{Abatacept}

Abatacept is recombinant fusion protein that binds to CD80 and CD86 thus preventing $\mathrm{T}$ cell co-stimulation by CD28 [41]. A 12-month, investigator-initiated, multicentre, double-blind, randomized, placebo-controlled phase 2 study was performed in early (disease duration $<36$ months) dcSSc patients [42]. Patients were randomized 1:1 to abatacept $125 \mathrm{mg}$ weekly subcutaneous or placebo. No background immunosuppression was allowed. The primary endpoints were as follows: modification in the mRSS and safety. Eighty-eight patients were enrolled. At 12 months, although a trend of efficacy could be observed, no significant difference in the mRSS was measured (- 6.24 in the abatacept group compared to -4.49 in the $\mathrm{PBO}$ group, $\mathrm{p}=0.28$ ), whereas HAQ-DI and some other composite measures significantly favoured abatacept-treated patients. Inflammatory gene expression significantly declined in patients treated with abatacept and the safety profile was satisfactory. Over the 6-month open-label extension, no new safety signals emerged. Moreover, clinically meaningful improvement in the mRSS was observed in both the abatacept and PBO groups when patients transitioned to abatacept supporting further studies of abatacept in dcSSc [43].

\section{Belimumab}

Blys is a cytokine expressed in B cell lineage cells that acts as a potent $B$ cell activator. It has been shown to play an important role in the proliferation and differentiation of B cells but it could also act on some innate immune cells like monocytes [44]. Belimumab is a recombinant antibody that binds to and inhibits soluble human BLys. Its biological activity causes mainly apoptosis of $\mathrm{B}$ cells and decreases autoantibody production [45]. A 52-week, investigator-initiated, single-centre, double-blind, placebo-controlled, pilot study was performed in early (disease duration $<3$ years) dcSSc patients recently started on mycophenolate mofetil [46]. Twenty patients were enrolled and randomized 1:1 to belimumab $10 \mathrm{mg} / \mathrm{kg}$ intravenously at a 2 -week interval for the first three doses and then at 4-week intervals until week 48 while also on mycophenolate mofetil therapy ( $1 \mathrm{~g}$ twice a day). At 52 weeks, no significant reduction in the mRSS was observed between the belimumab and the placebo group (median reduction -10 and -3 respectively, $\mathrm{p}=0.411$ ). No significant differences in the 
number of adverse events between the two groups were observed. Of note, a significant decrease in skin B cell signalling and profibrotic gene expression was observed in patients treated with belimumab.

\section{Riociguat}

Riociguat is soluble guanylate cyclase (sGC) stimulator with potential anti-fibrotic effects and proved efficacy in patients with pulmonary arterial hypertension associated with connective tissue diseases [47]. A 52 weeks, doubleblind, placebo-controlled, multi-centre, randomized phase 2 study was undertaken in early (disease duration $\leq 18$ months) dcSSc patients to investigate the potential effects on skin invovlement [48]. No background immunosuppression was allowed. In total, 121 patients were randomized $1: 1$ to either riociguat $0.5 \mathrm{mg}$ (up-titrated to a maximum dose of $2.5 \mathrm{mg}$ three times a day over 10 weeks). The primary endpoint of the study was the change in mRSS. Secondary endpoints included ACR CRISS, HAQ-DI, mRSS progression rate and change in \%predicted FVC. At 52 weeks, the primary endpoint was not met as the mean mRSS was not statistically different between the two groups: mean mRSS was $14.63 \pm 6.56$ for riociguat vs $15.73 \pm 10.48$ for placebo (least squares mean treatment difference - 2.34 [95\% CI - 4.99, 0.30; p $=0.08]$ ). Among the secondary endpoints, only the difference in mRSS progression rate showed a significant positive effect for riociguat patients $(-18 \%, \mathrm{p}=0.02)$. No significant adverse events were observed in the riociguat group.

\section{SAR100842}

SAR100842 is a selective oral antagonist of the lysophosphatidic acid receptor 1 (LPA1). Given its biological activity in stimulating mesenchymal cell migration and extracellular matrix production, LPA1 has been suggested to be implicated in the pathogenesis of SSc [49]. An 8-week, double-blind, randomized, placebocontrolled study followed by a 16-week open-label extension was performed in early (disease duration $<36$ months) dcSSc patients [50]. Patients could be on stable background immunosuppressive therapy. The primary endpoint was the safety and tolerability of SAR100842, while exploratory endpoints included gene signature in patients' skin biopsies. Seventeen patients were enrolled to receive either SAR100842 $300 \mathrm{mg}$ twice a day or placebo. At week 8 , the most common adverse events in SAR100842 patients were headache, diarrhoea and nausea. The mRSS reduction at week 8 was higher in the SAR100842 group compared to the placebo group but it was not statistically different $(-3.6$ versus $-2.8, \mathrm{p}=$ $0.46)$. LPA-related gene analysis in skin biopsies confirmed LPA1 target engagement.

\section{Lanifibranor}

Lanifibranor is a small molecule that activates all 3 PPAR isoforms. In preclinical SSc models, it was shown to reduce skin and lung fibrosis [51]. A phase 2 trial of lanifibranor (FASST study) has been performed in early (disease duration < 36 months) dcSSc patients. Background immunosuppression was allowed. The results of the trial have not been published yet but the preliminary results were press-released. A total of 145 patients were enrolled: 48 patients were treated with lanifibranor 1200 $\mathrm{mg}$ daily, 49 patients with lanifibranor $800 \mathrm{mg}$ daily and 48 with PBO. At 48 weeks, no significant change in the mRSS was observed among the three groups $(-3.7$ in the $800 \mathrm{mg}$ group, -4.3 in the $1200 \mathrm{mg}$ group and -4.9 in the placebo group). Lanifibranor was associated with a good safety profile with only one patient experiencing peripheral oedema in the $1200 \mathrm{mg}$ group.

Table 1 summarizes Phase $1-2$ trials.

\section{Phase 3 trials \\ Nintedanib}

Nintedanib is a multi-tyrosine kinase inhibitor which blocks FGF receptor-1, VEGF receptor-2 and PDGF receptor- $\alpha$ and $\beta$ [52]. Its anti-fibrotic and antiinflammatory activity was already demonstrated in preclinical models of SSc-ILD [53]. It is approved for the treatment of idiopathic pulmonary fibrosis [54]. A randomized, double-blind, placebo-controlled trial was performed in patients with SSc-ILD. Patients with early disease $(<7$ years), regardless of their disease subset, but with a high-resolution computed tomography showing $\geq$ $10 \%$ ILD were enrolled in a 1:1 ratio to either oral nintedanib $150 \mathrm{mg}$ twice a day or placebo (SENSCIS trial) [55]. Patients were allowed to be on stable background immunosuppression. The primary endpoint of the study was the annual rate of decline in FVC assessed. Secondary endpoints were as follows: absolute change in mRSS and the total score on the St. George's Respiratory Questionnaire (SGRQ). A total of 576 patients, the biggest trial on SSc ever, were enrolled: $52 \%$ of patients were $\mathrm{dcSSc}$ and $48 \%$ were receiving stable MMF therapy at baseline. Over the study period, the adjusted annual rate of change in FVC was significantly lower in the nintedanib group compared to the placebo group $(-52 \mathrm{~mL} /$ year versus $-93 \mathrm{~mL} /$ year, $\mathrm{p}=0.04)$. No significant modification was observed in the mRSS or in the SGRQ between the two groups. Of note, as the primary endpoint of the study was the annual rate of decline in FVC, both lcSSc (with low mRSS) and dcSSc patients were included in the study. No subgroup was identified as better responders although the combination of stable mycophenolate mofetil plus nintedanib provided the best scenario for prevention of decline. The most common adverse event reported, experienced by $76 \%$ of 
Table 1 Targeted therapies of Phase 1 and Phase 2 studies in SSc patients

\begin{tabular}{|c|c|c|c|c|c|c|c|}
\hline Trial drug & Target & Inclusion criteria & Treatment & IS & Endpoints & Duration & Results \\
\hline Inebilizumab & B cells (CD19) & $\begin{array}{l}\text { Localized } \mathrm{mRSS} \geq \\
2\end{array}$ & Single dose $0.1-10 \mathrm{mg} / \mathrm{kg}$ & Yes & $\begin{array}{l}\text { Safety } \\
\text { Tolerability }\end{array}$ & 12 weeks & $\begin{array}{l}\text { Safe and well- } \\
\text { tolerated }\end{array}$ \\
\hline Dabigatran & Thrombin & $\begin{array}{l}\text { SSC-ILD } \\
\quad \text { HRCT } \geq 20 \% \\
\quad \text { FVC }<70 \% \\
\text { Early ( } \leq 10 \text { years) }\end{array}$ & 75 mg twice a day & Yes & $\begin{array}{l}\text { Safety } \\
\text { Tolerability }\end{array}$ & 6 months & $\begin{array}{l}\text { Safe and well- } \\
\text { tolerated }\end{array}$ \\
\hline C-82 & $\beta$-Catenin Signaling & $\begin{array}{l}\text { Early (median } 8 \\
\text { months) } \\
\text { dcSSc (mRSS } \geq 12 \text { ) } \\
\text { Localized mRSS } \geq \\
2\end{array}$ & Topical formulation & Yes & $\begin{array}{l}\mathrm{AE} \\
\text { Gene } \\
\text { biomarkers }\end{array}$ & 4 weeks & $\begin{array}{l}\text { Well-tolerated } \\
\text { Weak genes } \\
\text { downregulation }\end{array}$ \\
\hline Pomalidomide & $\begin{array}{l}\text { Angiogenesis } \\
\text { immunosuppression }\end{array}$ & $\begin{array}{l}\text { SSC-ILD } \\
\text { FVC }>45>70 \\
\text { FVC }>70 \text {, recent } \\
\text { loss of } 5 \% \\
\text { HRCT }>20 \% \\
\text { Early (<7 years) }\end{array}$ & 1 mg/day & No & $\begin{array}{l}\text { \%pFVC } \\
\text { mRSS } \\
\text { SCTC GIT } 2.0\end{array}$ & 52 weeks & Negative \\
\hline Rilonacept & $\| \mathrm{L}-1$ & $\begin{array}{l}\text { Early (<24 months) } \\
\text { dcSSc (mRSS } \geq 15 \text { ) }\end{array}$ & $\begin{array}{l}320 \text { mg sc loading dose } \\
160 \text { mg sc weekly }\end{array}$ & No & $\begin{array}{l}\text { Change in } \\
\text { expression in } \\
2 \mathrm{G} \mathrm{SSc} \\
\text { genes } \\
\text { mRSS }\end{array}$ & 6 weeks & Negative \\
\hline Romilkimab & IL-4 and IL-13 & $\begin{array}{l}\text { Early ( } \leq 36 \text { months) } \\
\text { dcSSc (mRSS } \geq 10)\end{array}$ & 200 mg sc weekly & Yes & $\begin{array}{l}\text { mRSS } \\
\text { FVC/DLCO } \\
\text { HAQ-DI }\end{array}$ & 24 weeks & $\begin{array}{l}\text { mRSS difference - } \\
2.31(p=0.029) \text { in } \\
\text { favour of } \\
\text { Romilkimab }\end{array}$ \\
\hline Tocilizumab & IL-6 & $\begin{array}{l}\text { Early (<5 years) } \\
\text { dcSSc (mRSS } \geq 10)\end{array}$ & 162 mg sc weekly & No & $\begin{array}{l}\text { mRSS } \\
\text { FVC }\end{array}$ & $\begin{array}{l}48 \text { weeks } \\
\text { (primary } \\
\text { outcome } \\
\text { at } 24 \\
\text { weeks) }\end{array}$ & $\begin{array}{l}\text { mRSS change } \\
\text { favoured TCZ ( } p= \\
0.058) \\
\text { Smaller decrease in } \\
\text { FVC in TCZ }\end{array}$ \\
\hline Tofacitinib & JAK1 and 3 & $\begin{array}{l}\text { Early ( }<5 \text { years }) \\
\text { dcSSc (mRSS } \geq 10)\end{array}$ & 5 mg twice a day & Yes & $\begin{array}{l}\text { Grade } \geq 3 \\
\text { AE } \\
\text { mRSS } \\
\text { HAQ-DI } \\
\text { CRISS }\end{array}$ & 24 weeks & $\begin{array}{l}\text { No Grade } 3 \mathrm{AE} \\
\text { Improvement trend }\end{array}$ \\
\hline Pirfenidone & $\begin{array}{l}\text { Myofibroblast } \\
\text { TGF- } \beta \\
\text { STAT-3 }\end{array}$ & 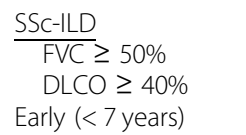 & $\begin{array}{l}\text { 2- or 4-week titration } \\
801 \mathrm{mg} \text { daily to } 2403 \mathrm{mg} \text { daily }\end{array}$ & Yes & $\begin{array}{l}\text { AE } \\
\text { FVC and } \\
\text { DLCO } \\
\text { PRO }\end{array}$ & 16 weeks & $\begin{array}{l}\text { 4-week titration } \\
\text { better tolerated } \\
\text { No change }\end{array}$ \\
\hline Lenabasum & $\begin{array}{l}\text { Cannabinoid } \\
\text { receptor } 2\end{array}$ & $\begin{array}{l}\text { Early }(<3 \text { years or }> \\
3 \text { years and }<6 \\
\text { years with CRP }>3) \\
\text { dcSSc }(\Delta \text { mRSS } \geq 5 \\
\text { last } 6 \text { months, total } \\
\text { mRSS } \geq 12)\end{array}$ & $\begin{array}{l}5 \mathrm{mg} / \text { day, } 20 \mathrm{mg} / \text { day or } 20 \mathrm{mg} \\
\text { twice a day for } 4 \text { weeks and then } \\
20 \mathrm{mg} \text { twice a day for } 8 \text { weeks. }\end{array}$ & Yes & CRISS & 16 weeks & $\begin{array}{l}\text { Improvement } \\
(p=0.044) \text { in } \\
\text { mRSS } \\
\text { PRO } \\
\text { PGA } \\
\text { HAQ-DI }\end{array}$ \\
\hline Abatacept & $\begin{array}{l}\text { B/T cells interaction } \\
\text { (CD80/CD86) }\end{array}$ & $\begin{array}{l}\text { Early dcSSc } \\
(\leq 18 \text { months, } \\
\text { mRSS } \geq 10 \\
>18 \text { and } \leq 36 \\
\text { months, mRSS } \geq \\
\text { 15) }\end{array}$ & 125 mg sc weekly & No & $\begin{array}{l}\text { mRSS } \\
\text { Safety }\end{array}$ & 12 months & $\begin{array}{l}\text { Negative } \\
\text { Good safety profile }\end{array}$ \\
\hline Belimumab & BLys & $\begin{array}{l}\text { Early ( } \leq 3 \text { years) } \\
\text { dcSSc (mRSS > 15) } \\
\text { recently started on } \\
\text { MMF ( } 2 \text { g) }\end{array}$ & $\begin{array}{l}10 \mathrm{mg} / \mathrm{kg} \text { iv 2-weekly for the first } \\
\text { three doses and then 4-weekly }\end{array}$ & Yes & $\begin{array}{l}\text { mRSS } \\
\text { Safety } \\
\text { Tolerability }\end{array}$ & 52 weeks & $\begin{array}{l}\text { No significant mRSS } \\
\text { change } \\
\text { Safe and well- } \\
\text { tolerated }\end{array}$ \\
\hline Riociguat & Guanylate Cyclase & $\begin{array}{l}\text { Early ( } \leq 18 \text { months) } \\
\text { dcSSc (mRSS } \geq 10)\end{array}$ & $\begin{array}{l}0.5 \mathrm{mg} \text { (up-titrated to a maximum } \\
\text { dose of } 2.5 \mathrm{mg} \text { three times a day) }\end{array}$ & No & $\begin{array}{l}\text { mRSS } \\
\text { CRISS } \\
\text { HAQ-DI } \\
\text { FVC }\end{array}$ & 52 weeks & $\begin{array}{l}\text { Negative Reduced } \\
\text { mRSS progression in } \\
\text { Riociguat }\end{array}$ \\
\hline SAR100842 & Lysophosphatidic & Early ( $\leq 36$ months) & 300 mg twice a day & Yes & Safety & 24 weeks & Safe and well- \\
\hline
\end{tabular}


Table 1 Targeted therapies of Phase 1 and Phase 2 studies in SSC patients (Continued)

\begin{tabular}{|c|c|c|c|c|c|c|c|}
\hline Trial drug & Target & Inclusion criteria & Treatment & IS & Endpoints & Duration & Results \\
\hline & acid receptor 1 & dcSSc (mRSS $\geq 15)$ & & & $\begin{array}{l}\text { Tolerability } \\
\text { mRSS }\end{array}$ & & $\begin{array}{l}\text { tolerated } \\
\text { No significant } \\
\text { change in mRSS }\end{array}$ \\
\hline Lanifibranor & PPAR & $\begin{array}{l}\text { Early ( } \leq 3 \text { years) } \\
\text { dcSSc (mRSS } \geq 10 \text { ) }\end{array}$ & $\begin{array}{l}400 \text { mg twice a day } \\
600 \text { mg twice a day }\end{array}$ & Yes & $\begin{array}{l}\text { mRSS } \\
\text { FVC and } \\
\text { DLCO } \\
\text { CRISS and } \\
\text { PRO }\end{array}$ & 48 weeks & $\begin{array}{l}\text { No significant } \\
\text { change in mRSS }\end{array}$ \\
\hline
\end{tabular}

IS immunosuppressive treatment, mRSS modified Rodnan skin score, SSC systemic sclerosis, ILD interstitial lung disease, HRCT high-resolution computed tomography, FVC forced vital capacity, AE adverse events, SCTC GIT Scleroderma Clinical Trials Consortium Gastrointestinal Tract, DLCO diffusing lung capacity for carbon monoxide, HAQ-DI Health Assessment Questionnaire - Disability Index, CRISS Combined Response Index in Systemic Sclerosis, PRO patient-reported outcome

nintedanib patients, was diarrhoea; however, it was usually mild and easily manageable with transient reduction of nintedanib and/or anti-diarrheic drugs. Nintedanib has been approved for the treatment of SSc-ILD by the FDA in 2019 and EMA in April 2020.

\section{Tocilizumab}

Given the encouraging results of the phase II trial of tocilizumab in SSc, a phase III, randomized, doubleblind, placebo-controlled, multi-centre trial was performed in early (<60 months) dcSSc [56]. Patients were assigned to either subcutaneously TCZ $162 \mathrm{mg} /$ week or placebo for 48 weeks. No background immunosuppression was allowed but patients could receive escape therapy from week 16 if they had a decline in FVC or from week 24 if they had a worsening in the mRSS or other SSc-related complications. The primary endpoint of the study was the change in the mRSS at week 48 , secondary endpoints were the change in \%predicted FVC at week 48 and time to treatment failure, defined as the time from first study drug treatment to the occurrence of the following SSc-related complications: death, decline in FVC $>10 \%$, increase in $\mathrm{mRSS}>20 \%$ and $\mathrm{mRSS}>5$ and other predefined SSc-related complications. A total of 212 SSc patients were enrolled. At week 48, the primary endpoint was not met. The improvement in the mRSS was higher in TCZ patients compared to placebo $(-6.1$ versus - 4.4) but it did not reach statistical significance
( $\mathrm{p}=0.098$ ). Nonetheless, the cumulative distribution of change in \%predicted FVC favoured TCZ compared to placebo $(-3.9$ versus $-0.6, \mathrm{p}=0.0015)$ and the mean difference in FVC change from baseline was $167 \mathrm{~mL}$ in favour of TCZ. A signal towards a higher time to treatment failure was observed in the TCZ group (hazard ratio: $0.63, \mathrm{p}=0.082$ ). Moreover, at week 48, TCZ was associated with a statistically significant higher median ACR CRISS score compared to PBO (0.89 versus 0.25 , p $=0.023$ ). Adverse events and serious adverse events were similar between the two groups. The sponsor will not move forward tocilizumab, but the good safety profile, the trend on skin outcomes and the stimulating lung preservation may open the door to further developments using other anti-IL6 agents or similar strategies. Table 2 summarizes Phase 3 trials.

\section{Observational studies Rituximab}

A cohort study was published in 2018 including SSc patients from the European Scleroderma Trials and Research network treated with RTX and who were compared to 9575 matched untreated SSc patients and selected using a propensity score matching strategy [57]. The aim of the study was to assess the real-life safety and efficacy profile of RTX in SSc. In total, 254 patients were treated with RTX for several reasons, the main being lung (58\%) and skin (32\%) involvement. After a

Table 2 Targeted therapies of phase 3 studies in SSc patients

\begin{tabular}{|c|c|c|c|c|c|c|c|}
\hline Trial drug & Target & Inclusion criteria & Treatment & IS & Endpoints & Duration & Results \\
\hline Nintedanib & $\begin{array}{l}\text { Tyrosine kinase inhibitors } \\
\text { (FGF, VEGF, PDGF) }\end{array}$ & $\begin{array}{l}\text { SSC-ILD } \\
\quad \text { HRCT } \geq 10 \% \\
\text { Early ( } \leq 7 \text { years) }\end{array}$ & $\begin{array}{l}150 \mathrm{mg} \\
\text { twice a day }\end{array}$ & Yes & $\begin{array}{l}\text { Annual rate of } \\
\text { decline (FVC) } \\
\text { mRSS } \\
\text { SGRQ }\end{array}$ & 52 weeks & $\begin{array}{l}\text { Reduced FVC decline in } \\
\text { nintedanib }(p=0.04) \\
\text { No change in mRSS or } \\
\text { SGRQ }\end{array}$ \\
\hline Tocilizumab & IL-6 & $\begin{array}{l}\text { Early ( } \leq 5 \text { years) dcSSc } \\
\text { (mRSS } \geq 10)\end{array}$ & $\begin{array}{l}162 \mathrm{mg} \mathrm{sc} \\
\text { weekly }\end{array}$ & No & $\begin{array}{l}\text { mRSS } \\
\text { FVC }\end{array}$ & 48 weeks & $\begin{array}{l}\text { No significant change in } \\
\text { mRSS ( } p=0.098) \\
\text { Change in FVC favoured TCZ } \\
(p=0.0015)\end{array}$ \\
\hline
\end{tabular}


median time of 2 years of follow-up, 70\% of RTX-treated patients had no side effects. Skin fibrosis improvement (change in mRSS) was more likely observed in RTX group (23 versus 14 events per 100 person-years, odds ratio 2.79 , $\mathrm{p}=0.002$ ). No significant rates of decrease were observed for \%predicted FVC or DLCO. Moreover, a significant higher propensity towards steroid withdrawal or tapering was found in RTX-treated patients (odds ratio 2.34, p < 0.0001 ) and a significant better lung outcome was found for ILD patients concomitantly treated with mycophenolate mofetil (delta \%pFVC 5.22, $\mathrm{p}=0.019$ ).

A further 24-week, open-label, randomized, controlled trial was performed to compare the efficacy and safety of RTX compared to intravenous cyclophosphamide (CYC) in early $(<3$ years) anti-toposiomerase I-positive dcSSc patients with ILD [58]. No background immunosuppressive treatment was allowed. The primary endpoint was the change in \%predicted FVC. Secondary endpoints were as follows: absolute change (in litres) of FVC, mRSS, 6-min walking test, Medsger's score and new onset or worsening of existing pulmonary hypertension by echocardiography. Sixty patients were randomized to either monthly pulses of CYC $500 \mathrm{mg} / \mathrm{m}^{2}$ or RTX $1 \mathrm{gr} \times 2$ infused 2 weeks apart. At 24 weeks, a significant improvement of the \%predicted FVC was observed in the RTX group compared to the CYC (61 to 67\% versus 59 to $58 \%$ respectively, $\mathrm{p}=0.003$ ). No significant differences were observed for the other secondary endpoints as the mRSS similarly improved in both the RTX and the CYC group. Serious adverse events were more commonly observed in the CYC group (pneumonia, premature ovarian failure and malignancy).

\section{Discussion}

SSc is characterized by multisystem organ involvement due to the interplay between vascular and immunological and fibrosis pathways [59]. SSc exhibits a remarkable heterogeneity with molecular heterogeneity mirroring the huge clinical one [1]. Recent findings regarding the participation and interaction of several markers and players have led to a better understanding of the pathogenesis of the disease and to the identification of new therapeutic targets. Moreover, improved screening and assessment strategies have promoted earlier detection, stratification and intervention. In addition, immense efforts have led to refine clinical trial design and cohort enrichment strategies, including stimulating biomarkers [60, 61]. There is general consensus about the use of immunosuppressants in early diffuse cutaneous SSc patients [62,63]. However, the shortcomings of traditional immunosuppressants in SSc, together with the brilliant success of biological DMARDs and small molecule synthetic drugs in inflammatory arthritis, have prompted the investigation of their potential benefits in
SSc. Following the paradigms established in inflammatory arthritis, it seems obvious that concurrent or sequential combination therapies will have to be investigated in SSc patients. This is highlighted in the context of SSc by the newly standard of care of upfront combination therapy achieved in pulmonary arterial hypertension [64]. The immediate great challenge thanks to the two recent phase 3 trials, investigating nintedanib [55] and tocilizumab [56], is that we have no evidence to stratify which patients should be treated with anti-fibrotics versus immunosuppression for the SSc-ILD patients. With regard to trial design and selected patients, it seems reasonable to position nintedanib as first-line for patients with established interstitial lung disease and lung fibrotic pattern both as monotherapy and in combination with mycophenolate mofetil. This has been recently further supported by the subgroup analysis of the SENSCIS trial on SSc-ILD patients who were on concomitant mycophenolate mofetil treatment at baseline where it has been shown that a smaller proportion of patients treated with nintedanib versus placebo (29\% versus $40 \%$ respectively; odds ratio $0,61[0,37-1,01]$ ) had a decrease in \%predicted FVC $\geq 3.3 \%$, which has been estimated to be the minimal clinically important difference for worsening of FVC in SSc-ILD patients [65]. Nonetheless, with the hope of a larger effect to counteract interstitial lung disease, the question of the timing of combination will have to be addressed quickly: generalization of upfront combination? Evaluation first in overlap patients? Restricted to patients failing first-line?

With regard to the other biologics, no firm conclusion can be drawn in the absence of rigorous randomized controlled trials. Nevertheless, it appears in the practice that several SSc patients who fail classical immunosuppressants given at first-line and who may have markers of active inflammation, biologically and or clinically, may receive targeted therapies towards inflammatory cytokines (tocilizumab, abatacept or rituximab). The recent promising patients' stratification strategies based on autoantibodies status (anti-topoisomerase I versus anti-RNApolymerase 3 versus anti-centromere etc.) and skin gene profiling offer the opportunity of selecting and identifying the best candidates for each targeted therapy [66]. Hopefully, ongoing or upcoming trials investigating targeted therapies may provide answers and open new avenues in a near future [67].

\section{Conclusions}

We have now an unprecedented arsenal of drugs as in SSc: some new and some already known. We have improved templates for performing clinical trials, and these drugs will be filtered rigorously to weight their risk/benefit ratio. There is a real hope that effective treatment may be available soon in SSc. Once validated, the next step will be to customize patientspecific therapeutics with the goal to develop precision medicine for SSc. 


\section{Abbreviations}

SSc: Systemic sclerosis; dcSSc: Diffuse cutaneous systemic sclerosis; ILD: Interstitial lung disease; DMARD: Disease-modifying anti-rheumatic drug; CYC: Cyclophosphamide; mRSS: Modified Rodnan skin score; RTX: Rituximab; TCZ: Tocilizumab; MMF: Mycophenolate mofetil; MTX: Methotrexate; POM: Pomalidomide; FVC: Forced vital capacity; PBO: Placebo; IS: Immunosuppressive treatment; HRCT: High-resolution computed tomography; FDA: Food and Drug Administration; EMA: European Medical Agency; PRISMA: Preferred Reporting Items for Systematic Reviews and MetaAnalyses; AE: Adverse events; RoBANS: Risk of Bias Assessment Tool for Nonrandomized Studies; SCTC GIT: Scleroderma Clinical Trials Consortium Gastrointestinal Tract; DLCO: Diffusing lung capacity for carbon monoxide; HAQ-DI: Health Assessment Questionnaire - Disability Index; CRIS S: Combined Response Index in Systemic Sclerosis; PRO: Patient-reported outcome; SGRQ: St. George's Respiratory Questionnaire; VEGF: Vascularendothelial growth factor; PF4: Platelet-factor 4; DAMPS: Damage-associated molecular patterns; TLR4: Toll-like receptor 4; IFNAR: Interferon receptor; JAK: Janus kinase; PPAR: Peroxisome proliferator-activated receptor; LPA: Lysophosphatidic acid receptor; ROS: Reactive oxygen species; TGF: Tissue growth factor; CTGF: Connective tissue growth factor; PDGF: Platelet-derived growth factor; ECM: Extracellular matrix

\section{Acknowledgements}

None.

\section{Authors' contributions}

CC and YA performed the literature review and wrote the whole manuscript. All authors read and approved the final manuscript.

\section{Funding}

This research did not receive any specific grant from funding agencies in the public, commercial or not-for-profit sectors.

\section{Availability of data and materials}

The datasets used during the current study are available from the corresponding author upon reasonable request.

\section{Declarations}

\section{Ethics approval and consent to participate}

Not applicable.

\section{Consent for publication}

Not applicable.

\section{Competing interests}

CC declares no conflict of interests relevant to the content of this article. YA reports personal fees from Actelion, Bayer, BMS, Boehringer and Curzion, and grants and personal fees from Inventiva, Roche and Sanofi.

\section{Author details}

'Unit of Immunology, Rheumatology, Allergy and Rare Diseases (UnIRAR) IRCCS San Raffaele Hospital, Vita-Salute San Raffaele University, Via Olgettina 60, 20132 Milan, Italy. ${ }^{2}$ Service de Rhumatologie, Hôpital Cochin, Université de Paris, 27 rue du Faubourg Saint-Jacques, 75014 Paris, France.

Received: 9 August 2020 Accepted: 19 May 2021

Published online: 01 June 2021

\section{References}

1. Denton CP, Khanna D. Systemic sclerosis. Lancet. 2017;390(10103):1685-99. https://doi.org/10.1016/S0140-6736(17)30933-9.

2. García Rodríguez LA, González-Pérez A, Michel A, Sáez ME. Contemporary epidemiology of systemic sclerosis: a population-based cohort study in the United Kingdom. Semin Arthritis Rheum. 2019;49(1):105-11. https://doi.org/1 0.1016/.j.semarthrit.2018.11.002.

3. Allanore Y, Simms R, Distler O, Trojanowska M, Pope J, Denton CP, et al. Systemic sclerosis. Nat Rev Dis Prim. 2015;1(1). https://doi.org/10.1038/ nrdp.2015.2.
4. Volkmann ER, Varga J. Emerging targets of disease-modifying therapy for systemic sclerosis. Nat Rev Rheumatol. 2019;15(4):208-24. https://doi.org/1 0.1038/s41584-019-0184-z.

5. Sato S, Hasegawa M, Fujimoto M, Tedder TF, Takehara K. Quantitative genetic variation in CD19 expression correlates with autoimmunity. J Immunol. 2000;165(11):6635-43. https://doi.org/10.4049/jimmunol.165.11.663 5.

6. Ward E, Mittereder N, Kuta E, Sims GP, Bowen MA, Dall'Acqua W, et al. A glycoengineered anti-CD19 antibody with potent antibody-dependent cellular cytotoxicity activity in vitro and lymphoma growth inhibition in vivo. Br J Haematol. 2011;155(4):426-37. https://doi.org/10.1111/j.13 65-2141.2011.08857.x.

7. Schiopu E, Chatterjee S, Hsu V, Flor A, Cimbora D, Patra K, et al. Safety and tolerability of an anti-CD19 monoclonal antibody, MEDI-551, in subjects with systemic sclerosis: a phase I, randomized, placebo-controlled, escalating single-dose study. Arthritis Res Ther. 2016;18(1):131. https://doi. org/10.1186/S13075-016-1021-2.

8. Ludwicka-Bradley A, Silver RM, Bogatkevich GS. Coagulation and autoimmunity in scleroderma interstitial lung disease. Semin Arthritis Rheum. 2011;41(2):212-22. https://doi.org/10.1016/j.semarthrit.2010.10.002.

9. Bogatkevich GS, Ludwicka-Bradley A, Nietert PJ, Akter T, van Ryn J, Silver RM. Antiinflammatory and antifibrotic effects of the oral direct thrombin inhibitor dabigatran etexilate in a murine model of interstitial lung disease. Arthritis Rheum. 2011;63(5):1416-25. https://doi.org/10.1002/art.30255.

10. Lumpkin $\mathrm{TB}$, et al. Direct thrombin inhibition with dabigatran alters the matrix-induced, pro-fibrotic phenotype of fibroblasts. Am J Respir Crit Care Med. 2018.

11. Silver RM, Wilson DA, Akter T, Atanelishvili I, Huggins JT, Kajdasz K, et al. Safety and tolerability of thrombin inhibition in scleroderma-associated interstitial lung disease. ACR Open Rheumatol. 2019;1 (7):403-11. https://doi. org/10.1002/acr2.11049.

12. Bastakoty D, Young PP. Wnt/ $\beta$-catenin pathway in tissue injury: roles in pathology and therapeutic opportunities for regeneration. FASEB J. 2016; 30(10):3271-84. https://doi.org/10.1096/fj.201600502R.

13. Hecht $A$. The $p 300 / C B P$ acetyltransferases function as transcriptional coactivators of beta-catenin in vertebrates. EMBO J. 2000;19(8):1839-50. https://doi.org/10.1093/emboj/19.8.1839.

14. Lafyatis R, Mantero JC, Gordon J, Kishore N, Carns M, Dittrich H, et al. Inhibition of $\beta$-catenin signaling in the skin rescues cutaneous adipogenesis in systemic sclerosis: a randomized, double-blind, placebo-controlled trial of C-82. J Invest Dermatol. 2017;137(12):2473-83. https://doi.org/10.1016/j.jid.2 017.06.032.

15. Weingärtner S, Zerr P, Tomcik M, Palumbo-Zerr K, Distler A, Dees C, et al. Pomalidomideis effective for prevention and treatment of experimental skin fibrosis. Ann Rheum Dis. 2012;71(11):1895-9. https://doi.org/10.1136/a nnrheumdis-2012-201784.

16. Oliver SJ, Moreira A, Kaplan G. Immune stimulation in scleroderma patients treated with thalidomide. Clin Immunol. 2000;97(2):109-20. https://doi.org/1 0.1006/clim.2000.4920

17. Hsu VM, Denton CP, Domsic RT, Furst DE, Rischmueller M, Stanislav M, et al. Pomalidomide in patients with interstitial lung disease due to systemic sclerosis: A phase II, multicenter, randomized, double-blind, placebo-controlled, parallel-group study. J Rheumatol. 2018:45(3):405-10. https//doi.org/10.3899/irheum.161040

18. McDermott MF. Rilonacept in the treatment of chronic inflammatory disorders. Drugs Today. 2009;45(6):423-30. https://doi.org/10.1358/dot.2 009.45.6.1378935.

19. Bonniaud P, Margetts PJ, Ask K, Flanders K, Gauldie J, Kolb M. TGF- $\beta$ and Smad3 signaling link inflammation to chronic fibrogenesis. J Immunol. 2005: 175(8):5390-5. https://doi.org/10.4049/jimmunol.175.8.5390.

20. Mantero JC, et al. Randomised, double-blind, placebo-controlled trial of IL1trap, rilonacept, in systemic sclerosis. A phase I/II biomarker trial. Clin Exp Rheumatol. 2018

21. Zhao Q. Bispecific antibodies for autoimmune and inflammatory diseases: clinical progress to date. BioDrugs. 2020;34(2):111-9. https://doi.org/10.1007/ s40259-019-00400-2.

22. Fuschiotti P. Role of IL-13 in systemic sclerosis. Cytokine. 2011;56(3):544-9. https://doi.org/10.1016/j.cyto.2011.08.030.

23. Allanore $Y$, Denton $C$, Khanna D, et al. Efficacy and safety of romilkimab in diffuse cutaneous systemic sclerosis (dcSSc): a randomized, double-blind, placebo-controlled, 24-week, proof of concept study [abstract]. Arthritis Rheum. 2019;71(suppl 10). 
24. O'Reilly S, Cant R, Ciechomska M, et al. Interleukin-6: a new therapeutic target in systemic sclerosis? Clin Transl Immunol. 2013;2(4):e4. https://doi. org/10.1038/cti.2013.2.

25. Desallais $L$, Avouac J, Frechet $M$, et al. Targeting $I L-6$ by both passive or active immunization strategies prevents bleomycin-induced skin fibrosis. Arthritis Res Ther. 2014;16(4):R157. https://doi.org/10.1186/ar4672.

26. Khan K, Xu S, Nihtyanova S, Derrett-Smith E, Abraham D, Denton CP, et al. Clinical and pathological significance of interleukin 6 overexpression in systemic sclerosis. Ann Rheum Dis. 2012;71(7):1235-42. https://doi.org/1 0.1136/annrheumdis-2011-200955.

27. De Lauretis A, et al. Serum interleukin 6 is predictive of early functional decline and mortality in interstitial lung disease associated with systemic sclerosis. J Rheumatol. 2013;40(4):435-46. https://doi.org/10.3899/jrheum.12 0725 .

28. Khanna D, Denton CP, Jahreis A, van Laar JM, Frech TM, Anderson ME, et al. Safety and efficacy of subcutaneous tocilizumab in adults with systemic sclerosis (faSScinate): a phase 2, randomised, controlled trial. Lancet. 2016; 387(10038):2630-40. https://doi.org/10.1016/S0140-6736(16)00232-4.

29. Hosseini A, Gharibi T, Marofi F, Javadian M, Babaloo Z, Baradaran B. Janus kinase inhibitors: a therapeutic strategy for cancer and autoimmune diseases. J Cell Physiol. 2020;235(9):5903-24. https://doi.org/10.1002/jcp.2 9593.

30. Wang W, Bhattacharyya S, Goncalves Marangoni R, et al. The JAK/STAT pathway is activated in systemic sclerosis and is effectively targeted by tofacitinib, August 2019. J Scleroderma Relat Dis. 5(2):239719831986536.

31. Goll GL, Kvien TK. New-generation JAK inhibitors: how selective can they be? Lancet. 2018. https://doi.org/10.1016/S0140-6736(18)31325-4.

32. Lescoat $\mathrm{A}$, Lelong $\mathbf{M}$, Jelijeli $\mathbf{M}$, et al. Combined anti-fibrotic and antiinflammatory properties of JAK-inhibitors on macrophages in vitro and in vivo: perspectives for scleroderma-associated interstitial lung disease. BiochemPharmacol. 2020;178:114103.

33. Khanna D, Bush E, Nagaraja $V$, et al. Tofacitinib in early diffuse cutaneous systemic sclerosis - results of phase I/II investigator-initiated, double-blind randomized placebo-controlled trial [abstract]. Arthritis Rheum. 2019; 71(suppl 10).

34. Noble PW, Albera C, Bradford WZ, Costabel U, Glassberg MK, Kardatzke D, et al. Pirfenidone in patients with idiopathic pulmonary fibrosis (CAPACITY): Two randomised trials. Lancet. 2011;377(9779):1760-9. https://doi.org/10.101 6/50140-6736(11)60405-4

35. Xiao H, Zhang GF, Liao XP, Li XJ, Zhang J, Lin H, et al. Anti-fibrotic effects of pirfenidone by interference with the hedgehog signalling pathway in patients with systemic sclerosis-associated interstitial lung disease. Int J Rheum Dis. 2018;21(2):477-86. https://doi.org/10.1111/1756-185X.13247.

36. Khanna D, Albera C, Fischer A, Khalidi N, Raghu G, Chung L, et al. An openlabel, phase II study of the safety and tolerability of pirfenidone in patients with scleroderma-associated interstitial lung disease: The LOTUSS trial. J Rheumatol. 2016;43(9):1672-9. https://doi.org/10.3899/jrheum.151322.

37. Gonzalez EG, Selvi E, Balistreri E, Akhmetshina A, Palumbo K, Lorenzini S, et al. Synthetic cannabinoid ajulemic acid exerts potent antifibrotic effects in experimental models of systemic sclerosis. Ann Rheum Dis. 2012;71(9): 1545-51. https://doi.org/10.1136/annrheumdis-2011-200314.

38. Zurier RB, Burstein SH. Cannabinoids, inflammation, and fibrosis. FASEB J. 2016;30(11):3682-9. https://doi.org/10.1096/fj.201600646R.

39. Spiera R, Hummers L, Chung L, Frech TM, Domsic R, Hsu V, et al. Safety and efficacy of lenabasum in a phase 2 randomized, placebo-controlled trial in adults with systemic sclerosis. Arthritis Rheum. 2020;72(8):1350-60. https:// doi.org/10.1002/art.41294.

40. Spiera R, Hummers $L$, Chung $L$, et al. Safety and efficacy of lenabasum at 21 months in an open-label extension of a phase 2 study in diffuse cutaneous systemic sclerosis subjects [abstract]. Arthritis Rheum. 2019;71(suppl 10).

41. Boleto G, Guignabert C, Pezet S, Cauvet A, Sadoine J, Tu L, et al. T-cell costimulation blockade is effective in experimental digestive and lung tissue fibrosis. Arthritis Res Ther. 2018;20(1):197. https://doi.org/10.1186/s13075-01 8-1694-9.

42. Khanna D, Spino C, Johnson S, Chung L, Whitfield ML, Denton CP, et al. Abatacept in early diffuse cutaneous systemic sclerosis: results of a phase II investigator-initiated, multicenter, double-blind, randomized, placebocontrolled trial. Arthritis Rheum. 2020;72(1):125-36. https://doi.org/10.1002/a rt.41055.

43. Chung L, Spino C, MCLain R, Johnson SR, Denton CP, Molitor JA, et al. Safety and efficacy of abatacept in early diffuse cutaneous systemic sclerosis (ASSE
T): open-label extension of a phase 2 , double-blind randomised trial. Lancet Rheumatol. 2020;2(12):e743-53. https://doi.org/10.1016/\$2665-9913(20)3023 $7-X$.

44. Sato S, Fujimoto M, Hasegawa M, Takehara K. Altered blood B lymphocyte homeostasis in systemic sclerosis: Expanded naive B cells and diminished but activated memory B cells. Arthritis Rheum. 2004;50(6):1918-27. https:// doi.org/10.1002/art.20274.

45. Boyce EG, Fusco BE. Belimumab: review of use in systemic lupus erythematosus. Clin Ther. 2012;34(5):1006-22. https://doi.org/10.1016/j. clinthera.2012.02.028.

46. Gordon JK, Martyanov V, Franks JM, Bernstein EJ, Szymonifka J, Magro C, et al. Belimumab for the treatment of early diffuse systemic sclerosis. Arthritis Rheum. 2018;70(2):308-16. https://doi.org/10.1002/art.40358.

47. Ghofrani HA, Galiè N, Grimminger F, Grünig E, Humbert M, Jing ZC, et al. Riociguat for the treatment of pulmonary arterial hypertension. N Engl J Med. 2013;369(4):330-40. https://doi.org/10.1056/NEJMoa1209655.

48. Khanna D, Allanore $Y$, Denton CP, Kuwana M, Matucci-Cerinic M, Pope JE, et al. Riociguat in patients with early diffuse cutaneous systemic sclerosis (RISE-SSc): randomised, double-blind, placebo-controlled multicentre trial. Ann Rheum Dis. 2020;79(5):618-25. https://doi.org/10.1136/annrheumdis-2 019-216823.

49. Zhao Y, Natarajan V. Lysophosphatidic acid (LPA) and its receptors: role in airway inflammation and remodeling. Biochim Biophys Acta Mol Cell Biol Lipids. 2013;1831(1):86-92. https://doi.org/10.1016/j.bbalip.2012.06.014.

50. Allanore Y, Distler O, Jagerschmidt A, Illiano S, Ledein L, Boitier E, et al. Lysophosphatidic acid receptor 1 antagonist SAR100842 for patients with diffuse cutaneous systemic sclerosis. Arthritis Rheum. 2018;70(10):1634-43. https://doi.org/10.1002/art.40547.

51. Ruzehaji N, Frantz C, Ponsoye M, Avouac J, Pezet S, Guilbert T, et al. Pan PPAR agonist IVA337 is effective in prevention and treatment of experimental skin fibrosis. Ann Rheum Dis. 2016;75(12):2175-83. https://doi. org/10.1136/annrheumdis-2015-208029.

52. Wollin L, Wex E, Pautsch A, Schnapp G, Hostettler KE, Stowasser S, et al. Mode of action of nintedanib in the treatment of idiopathic pulmonary fibrosis. Eur Respir J. 2015;45(5):1434-45. https://doi.org/10.1183/09031936. 00174914.

53. Huang J, Beyer C, Palumbo-Zerr K, Zhang Y, Ramming A, Distler A, et al. Nintedanib inhibits fibroblast activation and ameliorates fibrosis in preclinical models of systemic sclerosis. Ann Rheum Dis. 2016;75(5):883-90. https://doi.org/10.1136/annrheumdis-2014-207109.

54. Richeldi L, du Bois RM, Raghu G, Azuma A, Brown KK, Costabel U, et al. Efficacy and safety of nintedanib in idiopathic pulmonary fibrosis. N Engl J Med. 2014;370(22):2071-82. https://doi.org/10.1056/NEJMoa1402584.

55. Distler O, Highland KB, Gahlemann M, Azuma A, Fischer A, Mayes MD, et al. Nintedanib for systemic sclerosis-associated interstitial lung disease. N Engl J Med. 2019;380(26):2518-28. https://doi.org/10.1056/NEJMoa1903076.

56. Khanna D, Lin CJF, Kuwana M, et al. Efficacy and safety of tocilizumab for the treatment of systemic sclerosis: results from a phase 3 randomized controlled trial [abstract]. Arthritis Rheum. 2018;70(suppl 10).

57. Elhai M, Boubaya M, Distler O, Smith V, Matucci-Cerinic M, Alegre Sancho JJ, et al. Outcomes of patients with systemic sclerosis treated with rituximab in contemporary practice: A prospective cohort study. Ann Rheum Dis. 2019; 78(7):979-87. https://doi.org/10.1136/annrheumdis-2018-214816.

58. Sircar G, Goswami RP, Sircar D, Ghosh A, Ghosh P. Intravenous cyclophosphamide vs rituximab for the treatment of early diffuse scleroderma lung disease: Open label, randomized, controlled trial. Rheumatol. 2018. https://doi.org/10.1093/rheumatology/key213.

59. Brown M, O'Reilly S. The immunopathogenesis of fibrosis in systemic sclerosis. Clin Exp Immunol. 2019. https://doi.org/10.1111/cei.13238.

60. Denton CP. Challenges in systemic sclerosis trial design. Semin Arthritis Rheum. 2019:49(3):S3-7. https://doi.org/10.1016/j.semarthrit.2019.09.019.

61. Del Galdo F, Hartley C, Allanore Y. Randomised controlled trials in systemic sclerosis: patient selection and endpoints for next generation trials. Lancet Rheumatol. 2020;2(3):e173-84. https://doi.org/10.1016/S2665-9913(20)3 0007-2.

62. Kowal-Bielecka O, Fransen J, Avouac J, Becker M, Kulak A, Allanore Y, et al. Update of EULAR recommendations for the treatment of systemic sclerosis. Ann Rheum Dis. 2017;76(8):1327-39. https://doi.org/10.1136/annrheumdis-2 016-209909

63. Mendoza FA, Lee-Ching C, Jimenez SA. Recurrence of progressive skin involvement following discontinuation or dose reduction of Mycophenolate 
Mofetil treatment in patients with diffuse Systemic Sclerosis. Semin Arthritis Rheum. 2020;50(1):135-9. https://doi.org/10.1016/j.semarthrit.2019.06.012.

64. Coghlan JG, Galiè N, Barberà JA, Frost AE, Ghofrani HA, Hoeper MM, et al. Initial combination therapy with ambrisentan and tadalafil in connective tissue disease-associated pulmonary arterial hypertension (CTD-PAH): subgroup analysis from the AMBITION trial. Ann Rheum Dis. 2017;76(7): 1219-27. https://doi.org/10.1136/annrheumdis-2016-210236.

65. Highland KB, Distler O, Kuwana M, Allanore Y, Assassi S, Azuma A, et al. Efficacy and safety of nintedanib in patients with systemic sclerosisassociated interstitial lung disease treated with mycophenolate: a subgroup analysis of the SENSCIS trial. Lancet Respir Med. 2021;9(1):96-106. https:// doi.org/10.1016/S2213-2600(20)30330-1.

66. Quinlivan A, Ross L, Proudman S, et al. Systemic sclerosis: advances towards stratified medicine. Best Pract Res Clin Rheumatol. 2020;34(1):101469. https://doi.org/10.1016/i.berh.2019.101469.

67. Saunders P, Tsipouri V, Keir G, et al. Rituximab versus cyclophosphamide for the treatment of connective tissue disease-associated interstitial lung disease (RECITAL): study protocol for a randomized controlled trial. Trials. 2017;18(1):275. https://doi.org/10.1186/s13063-017-2016-2.

\section{Publisher's Note}

Springer Nature remains neutral with regard to jurisdictional claims in published maps and institutional affiliations. 